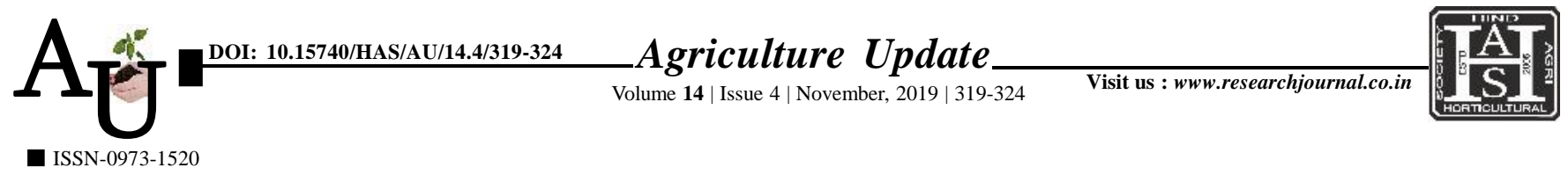

\title{
Research Article: Extent of adoption of recommended cultivation practices and constraints faced by sweet potato growers in Belagavi district
}

\author{
Chandrakanth V. Maradi and N. Manjula
}

Article Chronicle: Received :

18.09.2019;

Revised :

15.10.2019;

Accepted :

22.10.2019

KEY WoRdS:

Adoption,

Constraints,

Recommended

cultivation practices,

Sweet potato growers

Author for correspondence :

N. Manjula

Department of

Agricultural Extension

Education, College of

Agriculture, University

of Agricultural Sciences,

Dharwad (Karnataka)

India

Email: drmnuasd@gmail

com

See end of the article for

authors' affiliations
SUMMARY : The present study was conducted in Belagavi district of Karnataka state. The sample was drawn from the two taluka viz., Belagavi and Khanapur. Thus, 120 sweet potato growers were selected which constituted the sample respondents for the present study. Data were collected by personally interviewing the respondents with the help of pre-tested structured interview schedule in face to face situation. Collected data were tabulated with appropriate tools like frequency, percentage, mean etc. The majorresults of the study were, 46.67 per cent of the respondents belonged to medium adoption category in sweet potato cultivation. In case of specific adoption of recommended cultivation practices, cent per cent had fully adopted the recommended planting method and irrigation interval. Further a greater majority $(90.83 \%)$ of the respondents fully adopted the recommended June-July planting season, $(81.67 \%)$ recommended spacing and 70.83 per cent adopted seed rate per acreand 43.33per cent of the respondents partially adopted the plant protection measures against leaf spot disease, followed by non-adoption (36.67\%) and full adoption (20.00\%), respectively. Lastly three forth (75.83\%) of the respondents fully adopted the recommended harvesting time followed by 24.17 per cent of the respondents fell under partial adoption category. Problems faced by the farmers in production were of non-availability of labour, high cost of fertilizers and lack of finance. While price fluctuation, distant market and middlemen exploitation were the problems of marketing in sweet potato cultivation.

How to cite this article : Maradi, Chandrakanth V. and Manjula, N. (2019). Extent of adoption of recommended cultivation practices and constraints faced by sweet potato growers in Belagavi district. Agric. Update, 14(4): 319-324; DOI : 10.15740/HAS/AU/14.4/319-324. Copyright@ 2019: Hind Agri-Horticultural Society. 